\title{
Evaluasi desain sudu turbin gas model S-20 tipe aksial menggunakan CFD
}

\author{
Fatkur Rachmanu \\ Prodi Teknik Mesin Politeknik Enjinering Indorama \\ Jl. Kembangkuning, Jatiluhur, Purwakarta \\ Email: fatkur.rachman@gmail.com
}

\begin{abstract}
In the design of a gas turbine as a power plant, the turbine manufacturer always makes a redesign for improvement from the previous design (continuous improvement). This study discusses the redesign of a gas turbine for $S-20$ model power plant. The use of software that has been used to get more tangible from the basic theory of a gas turbine blade in this case is the average speed triangle. Can be seen a change in the flow of gas that enters the rotor and stator to be absorbed by the kinetic energy of the gas that hit the blade to produce a larger number of shaft paths. The results of this design produce for enthalpy in high pressure turbine is 1,211,129 J/kg, with mechanical power is 2,747 Watt. Produce view of shape is ellipse on leading edge and trailing edge and choice of twist turbine blade stating from hub, meridian and tip. In this research flow of gas depend on rotor turbine blade position and rotating speed of rotor. Besides that velocity of gas, gas mass, high of stator and rotor blade.
\end{abstract}

Keywords: Blade, turbine, gas, Saturn, Computational Fluid Dynamic (CFD).

\begin{abstract}
Abstrak
Dalam desain suatu turbin gas sebagai pembangkit listrik, di perusahaan pembuat turbin selalu melakukan desain ulang untuk perbaikan dari desain sebelumnya (continous improvement). Penelitian ini membahas desain ulang turbin gas untuk pembangkit listrik model $S$-20. Penggunaan perangkat lunak sudah digunakan untuk pendekatan yang lebih nyata dari teori dasar sudu turbin gas, untuk suatu segitiga kecepatan secara rata-rata. Dapat terlihat suatu perubahan aliran gas yang masuk pada sudu diam dan bergerak untuk diserap energi kinetik gas yang menabrak sudu untuk menghasilkan putaran poros yang sebesar-besarnya. Dalam desain ini menghasilkan untuk turbin tekanan tinggi (HPT) entalpi sebesar $1.211 .129 \mathrm{~J} / \mathrm{kg}$, dengan daya mekanik sebesar 2.747 Watt. Menghasilkan bentuk sudu elips pada leading edge dan trailing edge serta pemilihan sudu tipe berpilin (twist) mulai dari hub, meridian dan tip. Pada penelitian ini aliran gas bergantung pada posisi sudu dan kecepatan putar dari sudu bergerak. Selain itu kecepatan aliran gas, massa gas, tinggi sudu diam dan bergerak.
\end{abstract}

Kata kunci: sudu, turbin, gas, Saturn, Computational Fluid Dynamic (CFD).

\section{Pendahuluan}

Turbin aksial adalah suatu konfigurasi turbin yang paling umum untuk pembangkit tenaga listrik dan sistem pendorong/propulsi. Turbin aksial populer dipakai karena keserbagunaannya antara kapasitas daya dan berbagai kondisi operasi. Kapasitas daya turbin aksial dapat bervariasi dari puluhan $\mathrm{kW}$ untuk sistem tenaga. Turbin aksial adalah mesin putar yang mengubah energi dari aliran fluida menjadi kerja, turbin terdiri dari satu atau lebih tingkat secara seri dan setiap tingkat terdiri dari satu cincin sudu tetap (cascade stator blades) yang mempercepat aliran dan satu ring sudu jalan (cascade rotor blades) dimana membelokkan aliran, mengubah energi fluida/ gas menjadi kerja sebagai akibat dari perubahan arah dan dari momentum sudut serta menghasilkan daya luaran turbin. Model S-20 adalah diambil dari permodelan turbin gas Saturn-20 tetapi 
tidak sama persis, yang mana merupakan tipe turbin gas aksial. Karena desain sudu turbin gas banyak dilakukan di pabrikan luar negeri maka dalam artikel ini penulis mencoba untuk melakukan desain ulang pada turbin gas model S-20.

Desain sudu turbin gas pernah dilakukan oleh peneliti sebelumnya dan telah menggunakan perangkat lunak Fluent 4.0 yang menghasilkan variasi tekanan dan densitas fluida gas [1]. Selain itu penelitian desain turbin gas telah dilakukan dengan pengoptimalan desain turbin gas [2].

\section{Tinjauan Pustaka}

Di dalam ruang bakar fluida terbakar dengan persamaan reaksi kimia sebagai berikut sehingga menghasilkan gas [3]:

$$
\begin{gathered}
\mathrm{aCH} 4+\mathrm{bO} 2+\mathrm{cN} 2-->\mathrm{dCO} 2+\mathrm{eH} 2 \mathrm{O}+ \\
\mathrm{fN} 2+\text { Energi }
\end{gathered}
$$

Dimana a hingga $f$ adalah bilangan molekul. Maka unsur kimia yang paling besar dan masuk turbin tekanan tinggi (HPT) diambil serta diasumsi adalah $\mathrm{CO}_{2}$. Secara umum desain ulang pada turbin gas menggunakan prinsip segitiga kecepatan pada kecepatan aksial yang masuk sudu sehingga bahan bakar masuk pada ruang bakar dan bersama dari udara bertekanan menembakkan ke sudu jalan (rotor) secara arah radial roda turbin dengan tumbukan momentum.

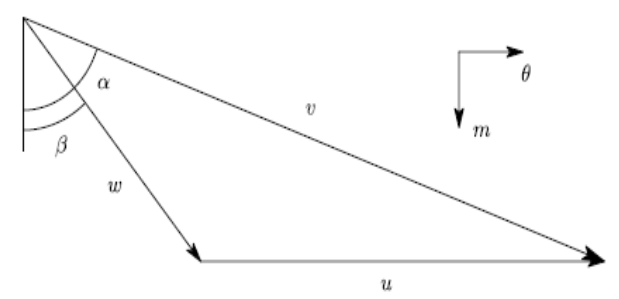

Gambar 1. Segitiga Kecepatan [2]

\section{Metode Penelitian}

Metode penelitian menggunakan studi literatur dan desain ulang serta perhitungan menggunakan bantuan komputer CAD dan CAE yaitu software-X kemudian disimulasikan menggunakan metode Computational Fluid Dynamic
(CFD) dengan paket Cosmos yang berada pada Solidworks (Flow Simulation). Dengan metode pendekatan aliran turbulen bersifat $\mathrm{k}-\varepsilon$ (kinetik dan disipasi), oleh Launder-Spalding dimana turbulen fluida tanpa adanya gesekan terhadap permukaan bidang yang dilalui gas tersebut juga dimana gradien tekanan tidak diperhitungkan [4].

Adapun data masukan pada sudu tingkat tekanan tinggi (HPT) adalah sesuai Tabel 1 [5][6].

Tabel 1. Tabel data masukan HPT

\begin{tabular}{ccc}
\hline No. & Parameter & Nilai \\
\hline 1 & Sudu HPT & $\begin{array}{c}\text { r2 }=0,46 \mathrm{~mm} \\
\text { r1 }=0,40 \mathrm{~mm}\end{array}$ \\
\hline 2 & $\begin{array}{c}\text { Putaran } \\
\text { poros }\end{array}$ & $15000 \mathrm{rpm}$ \\
\hline 3 & $\begin{array}{c}\text { Tekanan } \\
\text { masuk }\end{array}$ & $7,54 \mathrm{bar}$ \\
\hline 4 & $\begin{array}{c}\text { Aliran } \\
\text { massa }\end{array}$ & $5,8 \mathrm{~kg} /$ detik \\
\hline 5 & $\begin{array}{c}\text { Temperatur } \\
\text { fluida/gas }\end{array}$ & $1161 \mathrm{~K}$ \\
\hline 6 & Jenis gas & $\mathrm{CO}_{2}$ \\
\hline 7 & $\begin{array}{c}\text { Kecepatan } \\
\text { gas masuk } \\
\text { turbin }\end{array}$ & $\begin{array}{c}3,8 \mathrm{~m} / \mathrm{detik} \\
\text { (asumsi) }\end{array}$ \\
\hline
\end{tabular}

Dari data tersebut dimasukkan pada perangkat lunak (software-X) yang menghasilkan beberapa asumsi untuk bentuk sudu.

\section{Hasil dan Pembahasan}

Pada software- $X$ menggunakan perhitungan pembuatan bentuk sudu dari nilai-nilai yang dimasukkan dari Tabel 1, serta menggunakan profil sudu dalam hal ini bentuk sudu elips dipilih, termasuk pengambilan otomatis sudut serang (angle of attack) untuk memperkirakan lift dan drag. Sudut alfa dan beta yang dapat dipilih secara otomatis atau dimasukan nilainya. Dalam hal ini dipilih secara otomatis oleh komputer. 


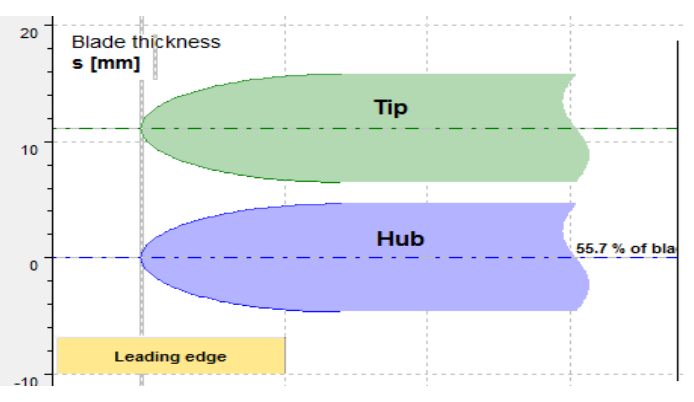

Gambar 3. Profil elips awal sudu bergerak

Gambar 3, memilih profil bentuk elips untuk sudu bergerak (rotor) pada darah awal sudu (leading edge). Untuk bagian akhir dibuat profil bentuk elips untuk sudu bergerak pada darah akhir sudu (trailing edge)

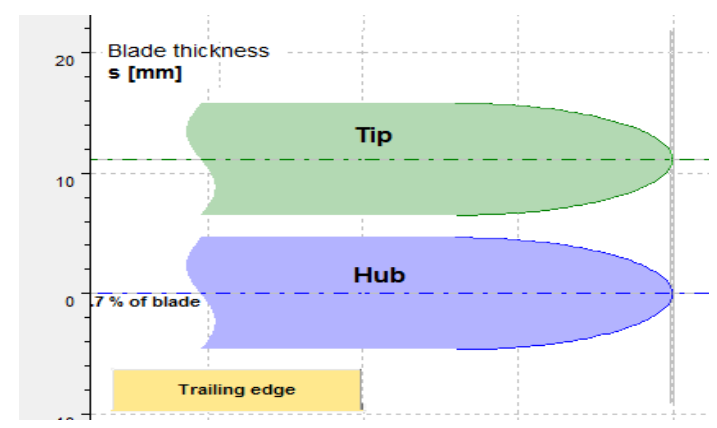

Gambar 4. Profil elips akhir sudu bergerak

Untuk sudu tetap (stator) menggunakan ujung elips sesuai Gambar 5, untuk bentuk di awal sudu tetap.

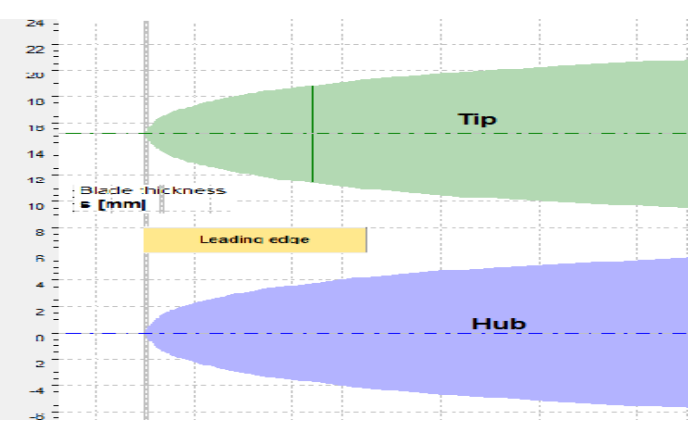

Gambar 5. Profil elips awal sudu tetap Gambar 6.

Dan ujung elips di akhir sudu sesuai

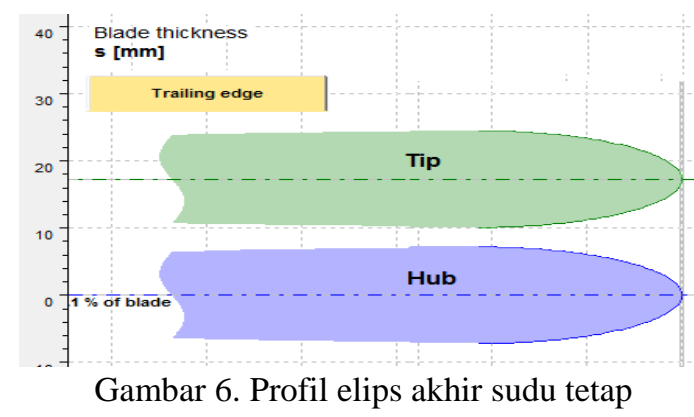

Dari perhitungan software- $X$ maka dapat menghasilkan quasi orthogonal pada rotor sesuai Gambar 7.

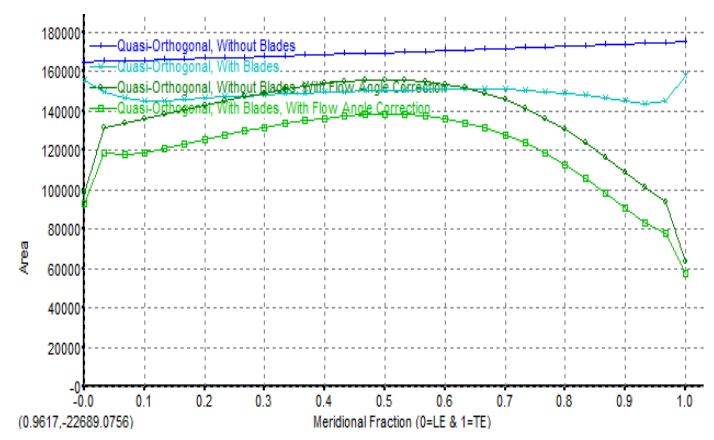

Gambar 7. Quasi orthogonal rotor

Quasi orthogonal rotor adalah grafik perbandingan pada sudu bergerak antara bidang meridional fraction pada ujung awal sudu $(L E)$ dan ujung akhir sudu (TE) terhadap area luasan sudu yang terkena fluida gas. Dari perhitungan software- $X$ maka dihasilkan quasi orthogonal pada stator sesuai Gambar 8.

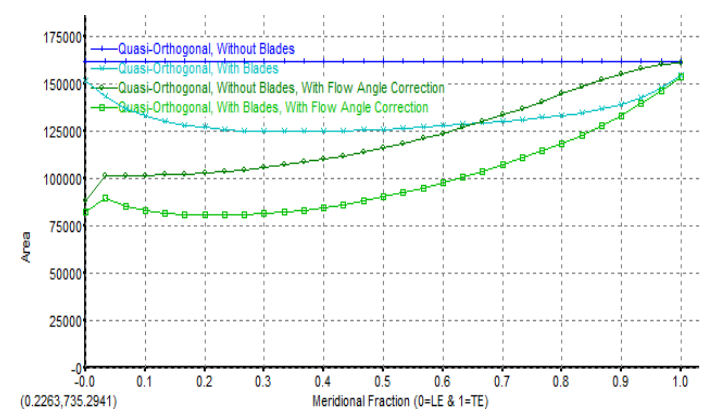

Gambar 8. Quasi orthogonal stator

Quasi orthogonal stator adalah grafik perbandingan pada sudu diam antara bidang meridional fraction pada ujung awal sudu (LE) dan ujung akhir sudu (TE) terhadap area luasan sudu yang terkena fluida gas.

Setelah melalui software-X maka menghasilkan gambar 3D yang dimigrasi menjadi gambar 3D dalam perangkat lunak Solidworks sesuai Gambar 9, berupa satu pasangan sudu diam (stator) dan sudu bergerak (rotor). 


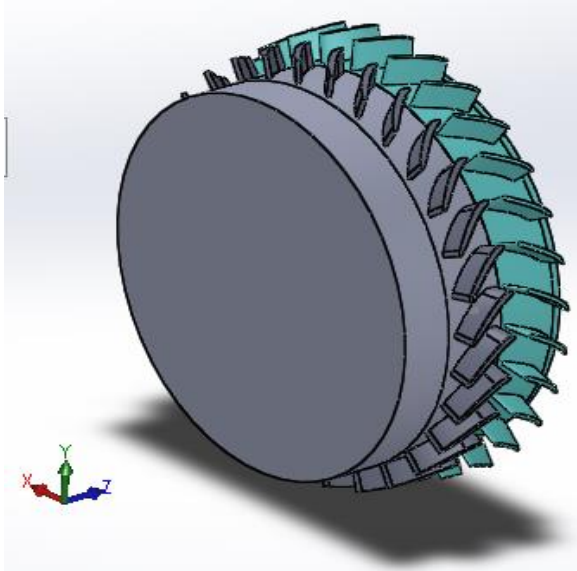

Gambar 9. Sudu Stator-Rotor

Kemudian dengan menu dinamika fluida dengan komputasi / Computational Fluid Dynamic (CFD) dari Solidworks untuk pilihan menu Flow simulation, dengan pendekatan jenis aliran turbulen menggunakan metode pendekatan turbulen model $(\mathrm{k}-\varepsilon)$ dan putaran rotor sebesar $15.000 \mathrm{rpm}$ merupakan putaran maksimum turbin tingkat tinggi (HPT) satu pasangan roda diam dan bergerak setelah gas keluar dari ruang bakar.

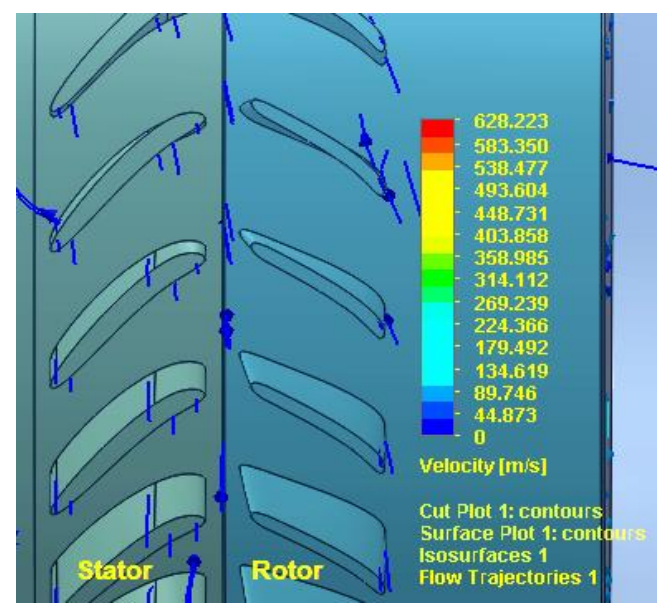

Gambar 10. Kecepatan Aliran $\mathrm{CO}_{2}$

Pada Putaran $\mathrm{n}=15.000 \mathrm{rpm}$

Dengan kecepatan aliran gas $\mathrm{CO}_{2}$ 3,8 m/detik . Maka menghasilkan Gambar 10, dimana kecepatan aliran gas $\mathrm{CO}_{2}$ sekitar $0 \mathrm{~m} /$ det hingga $3,8 \mathrm{~m} /$ detik.

Adapun arah aliran gas mengikuti arah putaran rotor searah jarum jam dilihat dari ujung keluar turbin gas (CW viewed from gas turbine outlet edge), serta bersifat turbulen sesuai Gambar 11.

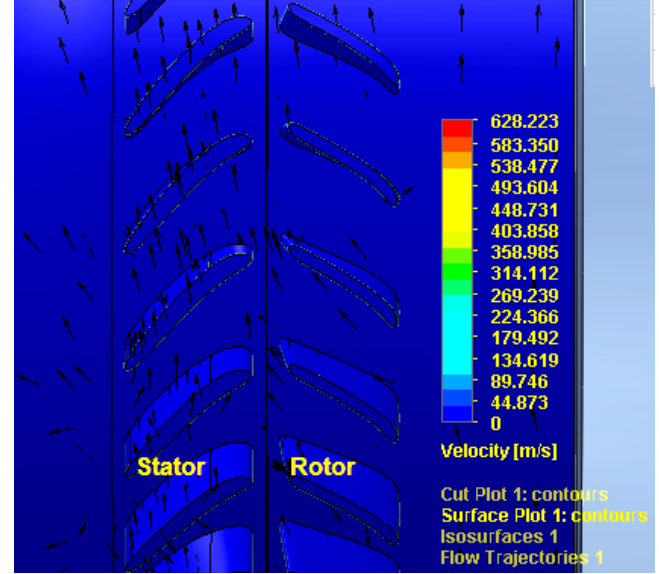

Gambar 11. Arah gas $\mathrm{CO}_{2}$ posisi surface plot.

Kecepatan berkisar $0 \mathrm{~m} /$ detik hingga $3,8 \mathrm{~m} /$ detik dan di beberapa kejadian akan melebihi dan dapat mencapai $5 \mathrm{~m} /$ detik disebabkan karena putaran roda jalan sudu bergerak (rotor disc blade) yang berputar $15.000 \mathrm{rpm}$. Terlihat bahwa gas hasil pembakaran masuk pada stator dan rotor untuk memutar rotor dengan arah searah jarum jam (dilihat dari bagian ke luar gas).

Pada Gambar 12, temperatur $\mathrm{CO}_{2}$ sebesar $1160 \mathrm{~K}$ hingga $1161 \mathrm{~K}$ akan terjadi penurunan suhu saat masuk stator dan keluar rotor.

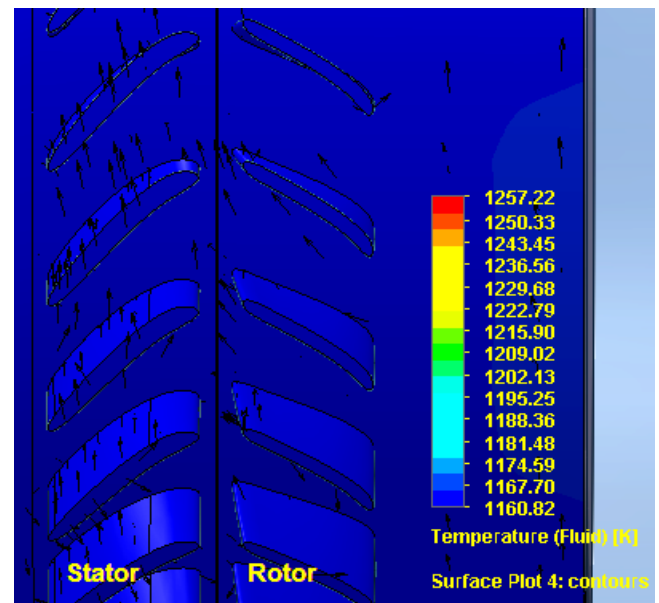

Gambar 12. Temperatur $\mathrm{CO}_{2}$

Untuk selanjutnya gas $\mathrm{CO}_{2}$ sesuai Gambar 13, tekanan fluida gas $\mathrm{CO}_{2}$ sebesar $750132 \mathrm{~Pa}$ hingga $754000 \mathrm{~Pa}$ sesuai tekanan gas masuk stator HPT.

Untuk kecepatan suara dari hasil perhitungan CFD menghasilkan Gambar 14, dimana bilangan Mach sebesar 0 hingga 0,09 tidak bersatuan. Pada perangkat lunak 
CFD ini dapat menunjukkan nilai torsi putar yang dihasilkan oleh rotor.

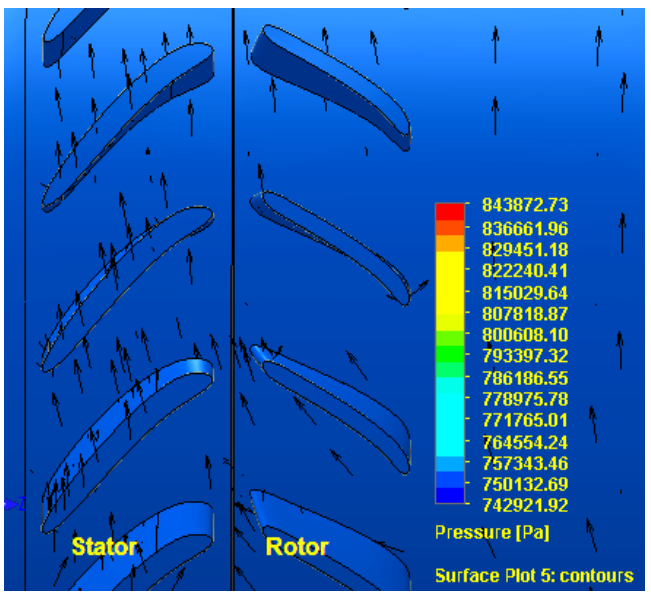

Gambar 13. Tekanan $\mathrm{CO}_{2}$

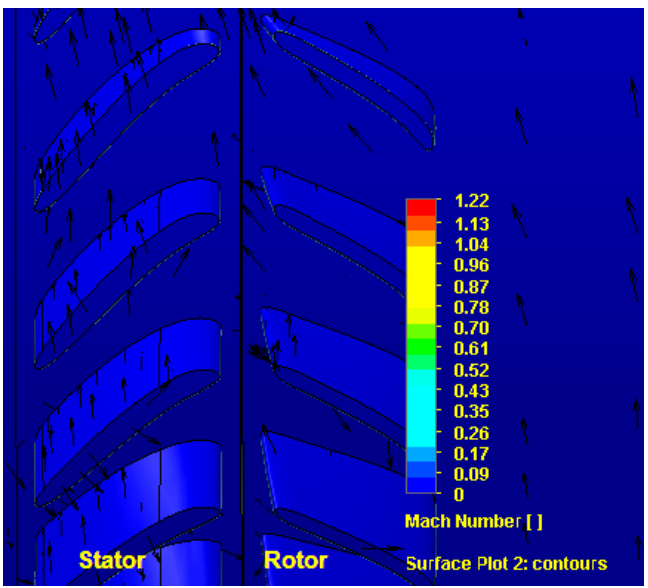

Gambar 14. Bilangan Mach

Disamping itu hasil CFD ini menghasilkan Torsi $=1.75 \mathrm{Nm}$. Sehingga Daya $=1,75 \times 2 \times 3,14 \times(15.000 / 60)$

$=2.747,5$ Watt

Untuk entalpi yang terjadi adalah 1.210.933 J/kg ditunjukkan pada Gambar 15.

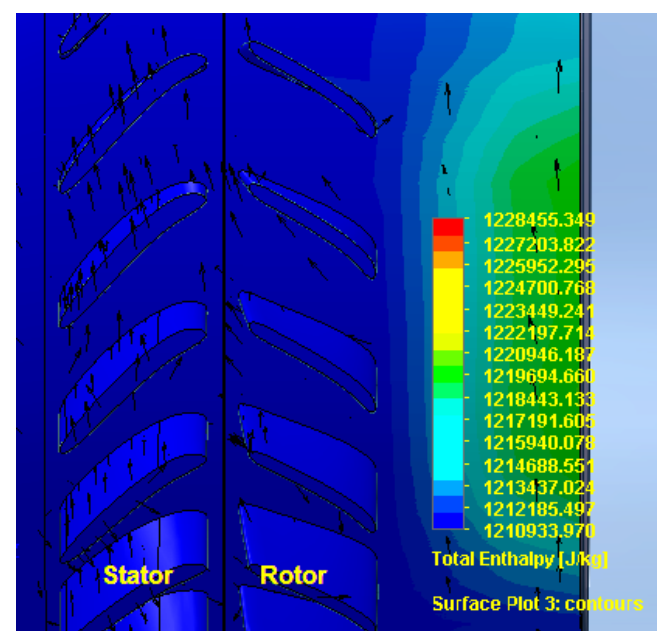

Gambar 15. Total Entalpi
Turbin gas saat berputar pada putaran normal sesuai standard API 616 dari grafik dapat diambil di bawah sekitar 5-10\% dari putaran maksimum.

Berikut putaran kontinyu normal dan posisi sudu stator dan rotor.

\section{Kasus 1}

Untuk sudu stator dan rotor yang sejajar maka didapat dengan menggunakan CFD sesuai pada Gambar 16.

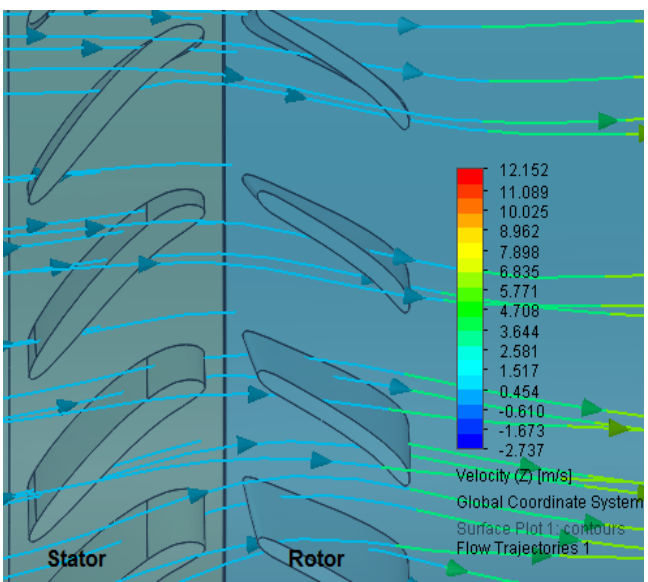

Gambar 16. Kecepatan Aliran $\mathrm{CO}_{2}$

Kecepatan aliran $\mathrm{CO}_{2}$ secara flow trajectories sebesar $0,454 \mathrm{~m} /$ detik saat masuk stator hingga 4,708 m/detik setelah melalui rotor.

Pada Gambar 17, kecepatan aliran gas $\mathrm{CO}_{2}$ secara surface plot sekitar 0,454 $\mathrm{m} /$ detik hingga $1,517 \mathrm{~m} /$ detik terlihat melalui celah antara sudu dan sebagian bersifat laminar dan turbulen.

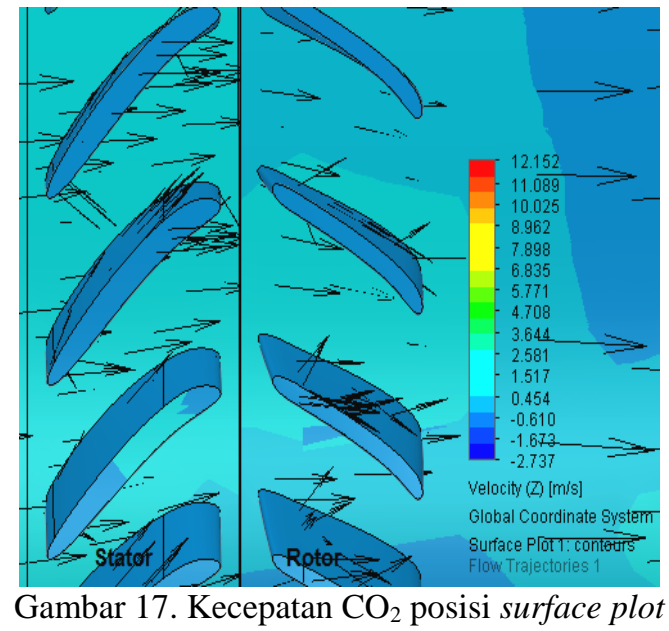

Untuk entalpi total dapat dilihat pada Gambar 18. Terlihat nilai entalpi total antara $1.211 .128 \mathrm{~J} / \mathrm{kg}$ hingga 1.211 .171 
$\mathrm{J} / \mathrm{kg}$ terutama entalpi tinggi pada daerah ujung atas sudu (tip) beberapa sudu stator dan sudu rotor.

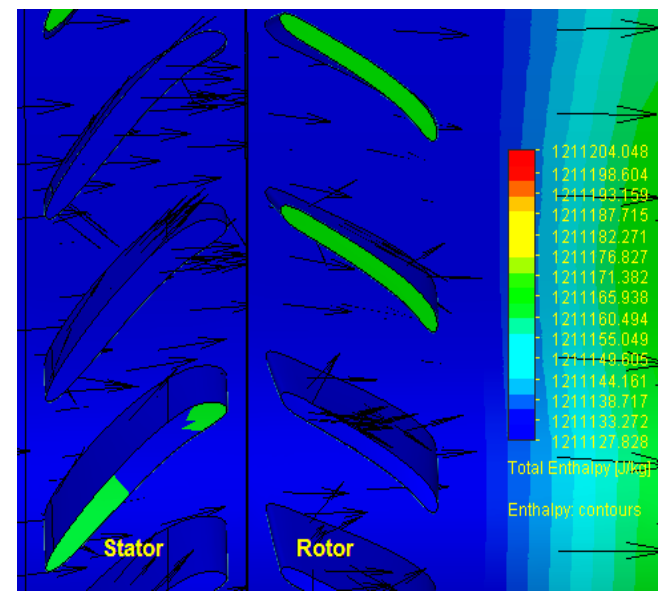

Gambar 18. Total Entalpi

\section{Kasus 2}

Untuk posisi di antara stator dan rotor dapat dilihat pada Gambar 19 sampai Gambar 21. Kecepatan pada sudu tidak sejajar pada Gambar 19.

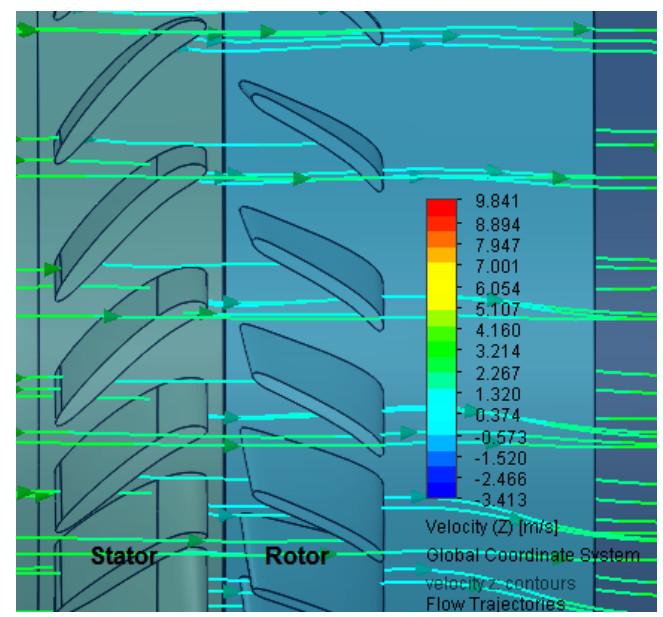

Gambar 19. Kecepatan Aliran $\mathrm{CO}_{2}$

Untuk kecepatan aliran secara flow trajectories dapat terlihat bahwa kecepatan mulai $0,273 \mathrm{~m} /$ detik hingga $3,214 \mathrm{~m} /$ detik dapat dibaca dengan skala warna.

Pada Gambar 20, untuk kecepatan posisi surface plot. Pada surface plot didapat kecepatan $\mathrm{CO} 2$ sebesar 0,374 $4,160 \mathrm{~m} /$ detik ini terlihat dari warna hijau kecepatan yang lebih tinggi masuk melalui stator kemudian kecepatan berkurang masuk ke rotor.

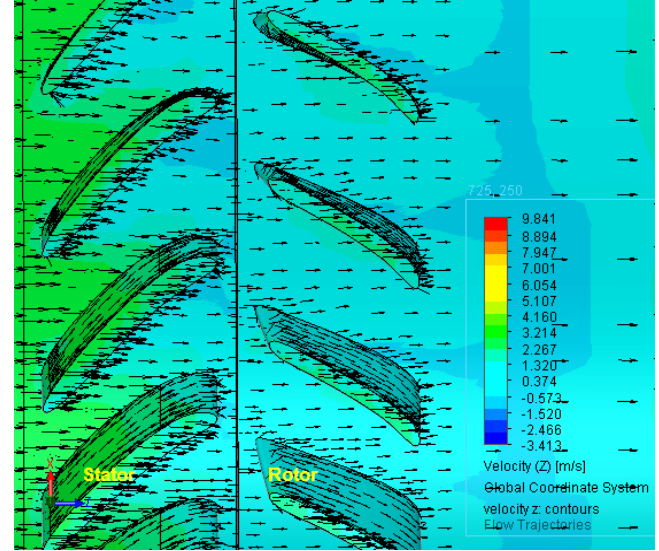

Gambar 20. Kecepatan Surface Plot

Pada surface plot didapat kecepatan CO2 sebesar 0,374 - 4,160 m/detik ini terlihat dari warna hijau kecepatan yang lebih tinggi masuk melalui stator kemudian kecepatan berkurang masuk ke rotor.

Adapun untuk entalpi total dapat dilihat pada Gambar 21.

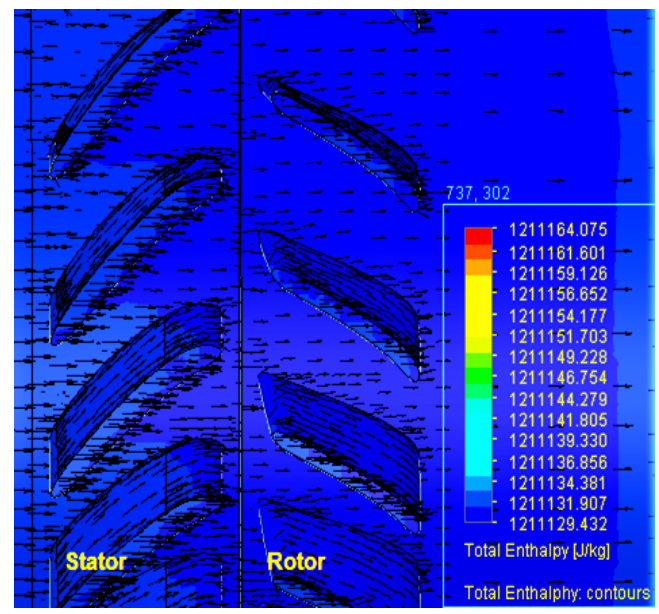

Gambar 21. Entalpi total

Pada Gambar 21, entalpi total bernilai $1.211 .129 \mathrm{~J} / \mathrm{kg}$ hingga 1.211 .134 $\mathrm{J} / \mathrm{kg}$. Maka secara umum hasil evaluasi pada posisi sudu sejajar, sudu tidak sejajar dan kecepatan putar maksimum menghasilkan entalpi total, nilai tertinggi yang dicapai adalah 1.211.191 J/kg pada posisi sudu tidak sejajar. Ini Disebabkan karena aliran gas dari sudu diam langsung diserap oleh sudu jalan pada posisi sudu tidak sejajar. Tetapi pada kecepatan putar maksimum entalpi yang diserap akan mengalami penurunan yang tinggi dan nantinya dapat diserap oleh dua pasang roda jalan turbin tingkat rendah (LPT). 


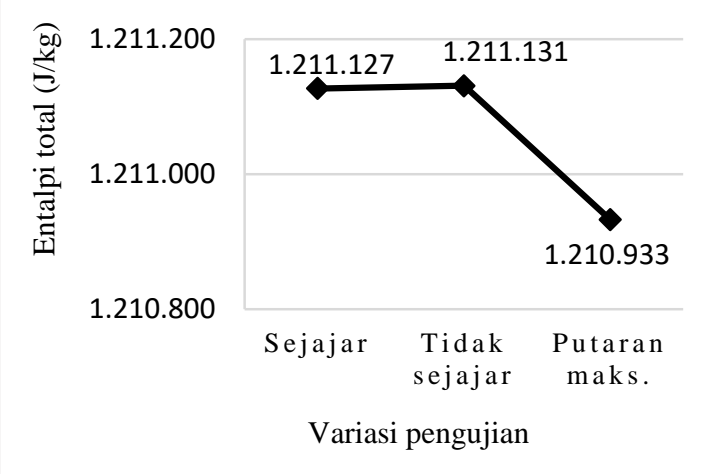

Gambar 22. Nilai entalpi total dari variasi pengujian

Pada Gambar 23, hasil pengujian pada sudu sejajar, sudu tidak sejajar dan kecepatan putar maksimum menghasilkan nilai torsi putar yang berbeda, nilai tertinggi sebesar 1,75 $\mathrm{Nm}$ dicapai pada kecepaan putar penuh. Kejadian ini akan ditambah menjadi torsi total oleh dua pasang roda diam dan jalan turbin tingkat rendah ( $L P T)$

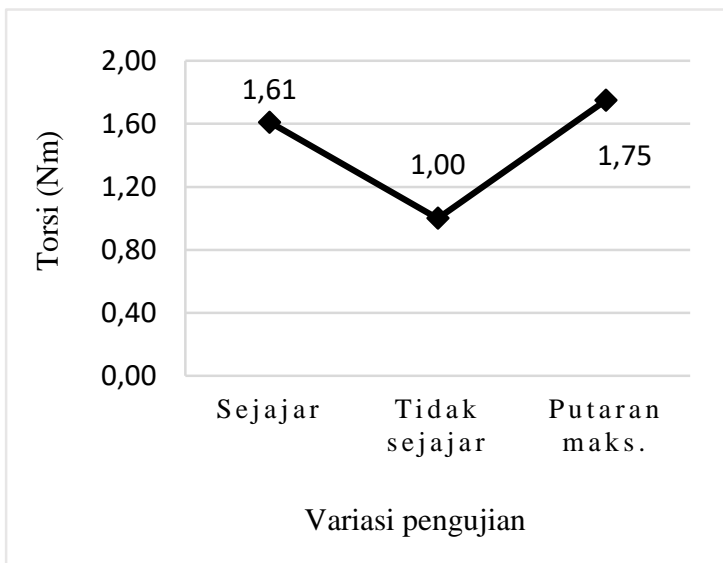

Gambar 23. Hasil nilai torsi putar dari variasi pengujian

\section{Kesimpulan}

Pada penelitian ini hasil aliran bergantung pada posisi sudu dan kecepatan putar yang dialami oleh sudu bergerak, selain itu kecepatan aliran masa gas, tinggi sudu diam dan bergerak. Adapun akan mengakibatkan turbulen yang besar jika putaran mencapai $15000 \mathrm{rpm}$. Penelitian ini belum melibatkan material dan konduksi, konveksi, pendinginan bagian dalam sudu. Masih dibutuhkan penelitian lebih lanjut yang lebih presisi, bentuk roda jalan dan tinggi sudu untuk memperbesar torsi putar, menambah kecepatan aliran gas masuk turbin saat putaran meningkat hingga maksimum serta sudut serang. Oleh sebab itu dibutuhkan perangkat lunak yang dapat menunjukkan efisiensi, torsi, dan daya yang dapat dibangkitkan oleh turbin tingkat tinggi (HPT) sehingga lebih optimal.

\section{Referensi}

[1] Rao, R. and Pandey, MN., 2014. Simulation of gas turbine blade for enhancement of efficiency of gas turbine using ANSYS. Journal Of Modern Engineering Research (IJMER), 46-51.

[2] Agromayor, R. and Nord, LO., 2019. Preliminary Design and Optimization of Axial Turbines Accounting for Diffuser Performance. Journal of Turbomachinery Propulsion and Power 4,32. 1-29.

[3] Muhamaddin, F., 2009. Perencanaan Turbin Gas Sebagai Penggerak Generator Listrik Dengan Daya Terpasang 135,2 MW, Skripsi, FTMesin USU,

[4] Informasi dari http://en.m.wikipedia. org/wiki/K-epsilon_turbulence_model (diakses pada Senin 20-April-2020)

[5] Rachmanu, F., 2018. Studi Kinerja Termodinamika Turbin Gas Model Saturn-20 Menggunakan Excel, Jurnal Elektra Vol 3 No.1 Januari,

[6] Rachmanu, F., 2017. Desain Ulang Kekuatan Sudu Turbin Gas Saturn-20 Akibat Gaya Sentrifugal Dengan Metode Elemen Hingga , Jurnal Elektra Vol 2 no.1 Januari. 